\title{
The trajectory of design/education at UFPE and the actions of RIDE
}

\author{
Solange Coutinho, \\ Teresa Lopes, \\ Natália Barbosa, \\ Renata Cadena
}

\section{INTRODUCTION}

This trajectory has stemmed from some of the inherent concerns within the political, economic and social contexts that have affected education in Brazil. All efforts made by previous governments - from 2002 to 2016, which even at the time were considered too late - have virtually been nullified by the current misgovernance since August 2016. With these efforts, it was believed that only a consistent, robust education project could overcome the daunting marks of historically constituted inequality, and thus of exclusion.

Currently, education is no longer treated as a priority on the national agen$\mathrm{da}$, nor is there any sign of an emancipatory education project being presented, which thereby leads to the formation, in Freire's terms, of a libertarian education. Quite the contrary, in fact: we are now faced with a pseudo-retrograde proposal that aims to control the knowledge involved in the education of our children and the young. According to an OECD study $(2017)^{1}$, Brazil is one of the countries that invests the least in primary and secondary education, spending around one third of most other countries. The barriers created by this are such that we run the risk of not being able to meet any of the goals established by the National Education Plan $(2014 / 2024)^{2}$, since the problem, in all its dimensions, has not yet been diagnosed, nor has action been taken to solve those that have already been identified.

1 OECD - The Organization for Economic Cooperation and Development. The study - Education at a glance from 11.09.2017. Forty-five countries were analysed and Brazil figured amongst the last, since the annual investment per pupil in primary education is $\mathrm{U} \$ 3,8000$, while the average investment in OECD countries is U\$ 10.,500. For the complete study see http//oecd.org. Viewed 15-01-2018.

2 Please see http://www.pne.mec.gov.br. Viewed 15-02-2017. 
It is important to clarify that the investigative actions presented herein do not account for the severity, and increasing uncertainty, of the problem regarding education in Brazil, nor was this an objective. Nevertheless, the projects intend to contribute to an approximation between the fields of design and education in order to stimulate the debate, thereby exposing the limits and the possibilities that affect the links involved - particularly regarding the use made of graphic language $(\mathrm{GL})^{3}$ within the educational environment (Coutinho and Lopes, 2011).

As a starting point, the projects address the dynamics of information design for education regarding that which is considered central: the effectiveness and efficiency of information systems, especially in the relationship between image and verbal production. Coutinho and Lopes (2011) have previously highlighted that this production implies two central processes: those that involve the formation of teachers and their development as originators and consumers of information; and those that deal with the formation of students and their strategies as originators and consumers of information. Ultimately, based on the assumption that students and teachers are originators ${ }^{4}$ of graphic information, we understand that the knowledge derived from information design is strategic for the process of expanding the visual experience and the configuration of educational artifacts that mediate knowledge.

In a broader approach, Fontoura (2002) defends design as a mediating activity, which gives material form to intellectual concepts, and is one way of solving contemporary educational conflicts. It is also the conceptualization of materialized ideas through the use of technologies. Thus, it is a union of its fundamentals, work methodologies, ways to interact in the formation of material culture, ways to proceed in the conception of objects, of needing to be familiar with technologies and materials, and of reinforcing the idea that design may be an essential tool for the field of education (Fontoura, 2002; Coutinho and Lopes, 2011; Lopes, 2014).

In this chapter, we aim to describe the efforts of a determined group of researchers at the Universidade Federal de Pernambuco (UFPE), with a view to consolidating experiences that have been developed in Pernambuco over the last fif-

3 For graphic language, we have adopted the concept proposed by Twyman (1979, p. 118), which understands graphic as '[...] drawn or otherwise made visible in response to conscious decisions' and language as 'the vehicle of communication'.

4 We adopted the terminology used by Twyman $(1979,2002)$ in his schema to study graphic language, in which he considers an 'originator' as the individual, specialist or non-specialist, who generates GL and a 'consumer' as the individual, specialist or non-specialist, who receives the information through GL. 
teen years. The timeline below demonstrates the four key moments of this sequence, herein termed:

- 2003 - 2007 | Exploratory Phase (1), during which the preliminary actions in schools and in the field of education were developed;

- 2008 - 2011 I Teaching Design I (2), during which constitutional actions/ processes were developed within the field of design together with an analysis of educational artifacts;

- 2012 - 2016 | Teaching Design II (3), during which studies were developed involving aspects and methods for formation proposals, as well as incorporating the paradigm of digital education and approaches such as in the field of sociology; and,

- 2016 - 2020 I RIDE (4), during which actions for formation and educational devices are being conducted in order to solidify the new field of design/education, concomitantly with the creation of the International Design/Education Network (referred to in Brazil as RIDE).

\section{EXPLORATORY PHASE [2003/2007]}

In this first stage, research was conducted within two major themes: (1) the study of the drawing process (observation and memory) as produced by pupils and teachers at schools in Recife ${ }^{5}$, and (2) the study of graphic language (verbal, pictorial and schematic) presented within the school context.

Five studies were conducted during this period, coordinated/supervised by Solange Coutinho with the following projects and participants:

a) A graphic analysis of visual messages in schools in Recife - Patrícia Baía Vanderlei;

b) Digital illustrations in children's books: an analysis of techniques and style - Thiago Lyra;

c) The semantic function of images in children's textbooks in Portuguese Verônica Emília Campos Freire;

d) A graphic project: a collection of primary school textbooks - José Fábio Luna da Silva; and

e) Design and Education: a discussion on introducing notions of graphic design as an activity on the arts education syllabus for Brazilian Primary

5 With regard to research on the process of children's drawing, during this period, please see Coutinho, 2006. 
Education, and an initial proposal of contents for this activity - Olívia Morim de Melo.

The researchers visited twenty public (municipal and state) and private schools in the city of Recife to investigate visual discourse. They evaluated graphic artifacts produced manually by teachers and pupils with the use of a tool (photocopy/mimeograph), as well as printed material (textbooks, posters). The artifacts most commonly used as educational and informational support - in both public and private schools -, within the context of this period, besides the board, were grouped as follows: (a) what we classified as visual messages (murals, posters, notices, and others); (b) worksheets, conceived and produced by teachers (Figures $1 \mathrm{a}$ and $1 \mathrm{~b}$ ); and (c) the textbook, printed and produced outside the school environment by experts (including designers), although selected by coordinators and teachers.
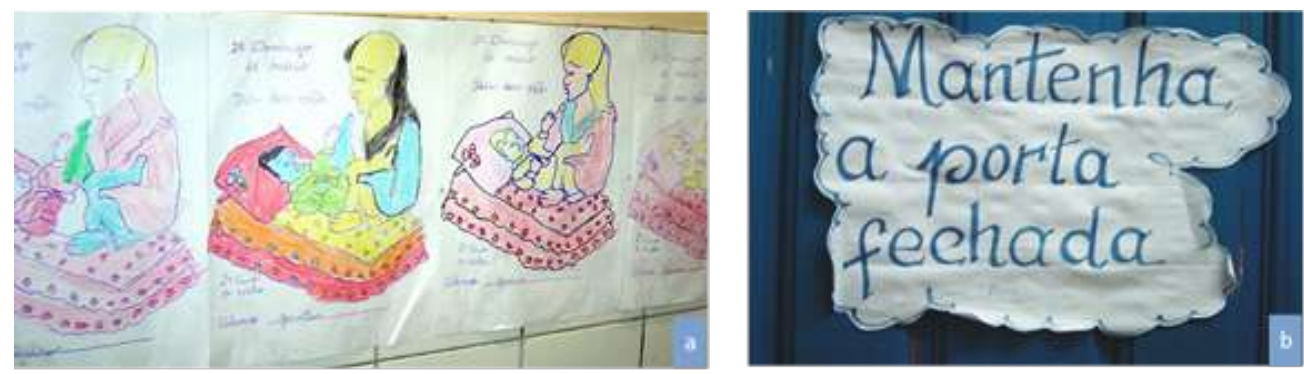

Figure 1: (a) mimeographed colouring pages and (b) a notice to keep the classroom door closed. (Source: Coutinho and Freire, 2007a).

These visual messages were grouped by Vanderlei and Coutinho (2003) as: (a) birthdays; (b) characters from children's stories; (c) seasonal dates; (d) educational materials; (e) attendance list; and (f) educational and/or informative messages. On the other hand, lesson plans used almost daily to provide support for pedagogical activities developed in several disciplines are usually monochromatic and reproduced in low resolution (mimeograph or photocopy). ${ }^{6}$

As a result, a restricted use of images was observed in the compositional

6 The theoretical-analytical basis used as a parameter for the analyses were as follows: the principles /of the compositional laws of Fabris (1973) and Dondis (1999); and for the specialized analysis, Twyman's schema for the use of graphic language (1979) and Goldsmith (1980, 1984). 
elements. The content of many illustrations introduced no additional meaning to the accompanying texts, thereby functioning simply as decorative elements, except in certain educational activities. It was observed that although there is a large quantity of visual messages in the school environment, those responsible for creating them make little use of the many possibilities available for production methods and modes of symbolization.

Research conducted by Freire (2005), examined the semantic issues of illustrations presented in three Portuguese Language textbooks for the second year of primary school. ${ }^{7}$ The images were analysed within the context of the books, seeking to understand the relationship between form and content, from the desired meaning for the demands of the exercise in question. ${ }^{8}$ These particular artifacts were selected since were being used by children who were learning to read, i.e., they were able to read and were in the process of acquiring language for reading and writing. We would emphasize that the textbook, even though it was supported by a whole set of communicational artifacts within the school environment, played a central role in the system, particularly in the case of reusable textbooks - where pupil fill in the answers to questions posed by the authors. ${ }^{9}$

When studying Portuguese, especially when learning to read, it is through illustrations that children recognize the "reference" image of the "first words". This signifies that in the process of learning to read and write the correct association of the word, in its visual form, with a meaning, through an image, becomes key to comprehending the whole.

Figure 2 presents some of the illustrations found in textbooks, from which Freire (2005) constructed the following categories/semantic problems: (a) Incoherence between image content and the response requested by the author (reflection and navel, respectively could also represent mirror and belly, for example); (b)

7 Língua Portuguesa 2, Viver e Aprender - Português 2 and Descobrindo a Gramática 2 .

8 It should be noted that children's textbooks are chosen by educational agents (coordinators and/or teachers) from a list sent by the Ministry of Education, after evaluation by specialists in the areas.

9 In addition to being a profitable business for Brazilian publishers, as figures indicate for the period, for the academic years between 1995 and 20051.026 billion books were acquired and distributed to 30.8 million students per year, with an investment of R \$ 3,7 billion. Data demonstrates that for the year 2017 alone, $\mathrm{R} \$ 1,3$ billion was invested in textbooks for 32 million students from 117 thousand public schools, thereby illustrating that the profits of the country's major publishing companies continue to grow. 
incoherence between the repertoire and the age group of users (beep, hydrangea, mint, coati - a type of "cat hunter": horse/dog/cat, as termed by one of the children); (c) graphic imprecision, i.e., complex and/or very small representations and/or inconsistent perspectives and/or use of colour (hydrangea, sausage).

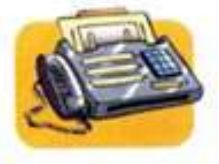

fax

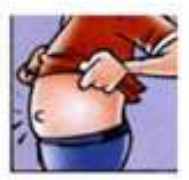

umbigo

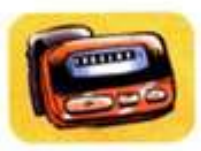

bipe

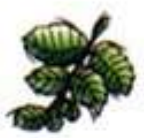

hortela

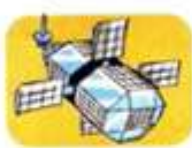

satélite

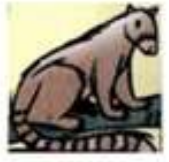

quati

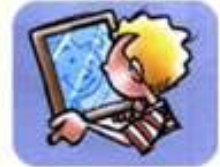

reflexo

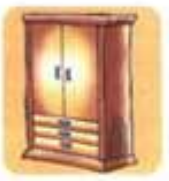

armário

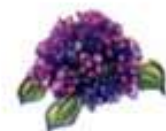

hortẽnsia

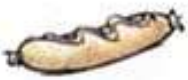

salsicha

Figure 2: set of illustrations analysed by FREIRE (2005).

As a result of this phase, ${ }^{10}$ with regard to the use of graphical artifacts in schools in Recife, ${ }^{11}$ we now understand that the informational system was (and still is) inaccurate and requires a process of rethinking. Practices, especially in public schools, seem stagnant and incompatible with information present in the external context, although at the same time, we encountered teachers who were receptive to adjusting their knowledge, and willing to understand the processes involved in selecting materials. From the results of this first stage, it was possible to structure Teaching Design I, as explained below.

\section{TEACHING DESIGN I [2008/2011]}

With this collection of projects, the intention was to provide a reflexive, exploratory investigation of the teaching practice biased towards design - particularly, the use of graphic language in schools, which as we have observed, is often inconsistent.

Fontoura (2002) has indicated that the task of a school is, and in the future

10 Results published in: Vanderlei and Coutinho, 2003; Freire, 2005; Coutinho, 2006; Coutinho and Freire 2007a, 2007b; Coutinho and Silva, 2007.

11 It is important to remember that these books are adopted all over the country. 
will be even more so, to provide a place in which to construct knowledge, taking into account the needs and capacities each individual learner. The aim therefore, should be to train professionals who are better prepared and more able to cope with the future changes brought about by the continuous advances produced by society. This is especially important within the current context where we encounter an imbricated process in which the various graphic languages are expanding and/or synthesising (as is the case of emojis), together with the innumerable communication variables, provoking a subjective current of cultural signs and providing support for an unprecedented informational ecosystem network.

By considering school as the locus of participatory learning between the various actors, where there is an exchange, sharing (or should be), and the production and reproduction of graphic information, we therefore understand that within this space, there is a continuous, dialogical living system of feedback. However, we also perceive that this system does not always evolve, and may appear stagnant or involuted, when we compare it to what is outside the walls. This realization is aggravated when we understand that the use to which we put GL is, at the very least, neglected in both educational environments and educational artifacts. The reasons for this are innumerable and indeed some of them became the subject of research conducted during this phase.

Teaching Design I, therefore, aimed to study the use (the understanding and generation) of the most common mediators of information in the educational environment (textbooks, workbooks, the board) used by pupils and teachers, in order to understand that contents, originating from graphic design, could be useful to primary education in Brazil. The specific objectives involved exploring the legal ambience and school practices by: (1) investigating the existing parameters of educational legislation (referred to as LDBEN and PCNs), and their appropriateness to contexts, both in and outside school; (2) knowing how the PCNs are adopted into school practice with regard to constructing visual language; (3) identifying which elements of graphic design (graphic language) may constitute appropriate curricular contents for the construction of a visual culture; and (4) developing a methodology to adopt these contents in the curriculum of Brazilian primary education. The schema of Figure 3 represents a cross section of the Teaching Design I project, indicating the focus of the proposal centred on the material and symbolic artifacts that were investigated while being used, as well as the teacher's participation as originator of visual information. 


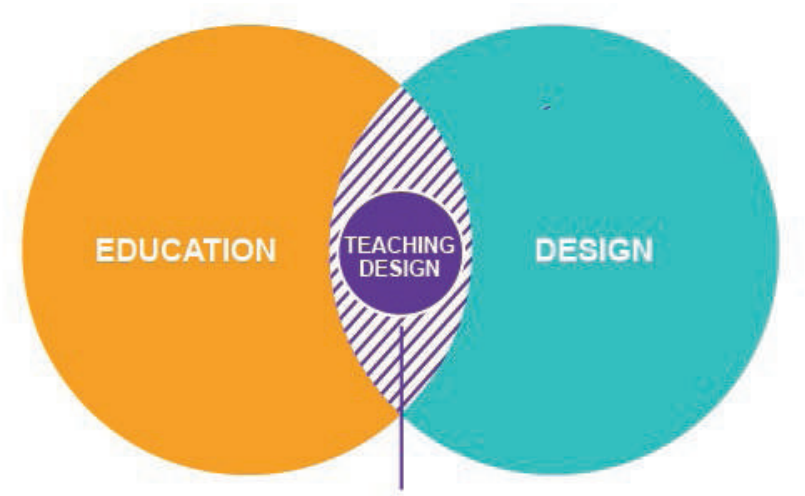

\section{Graphic Language in the school}

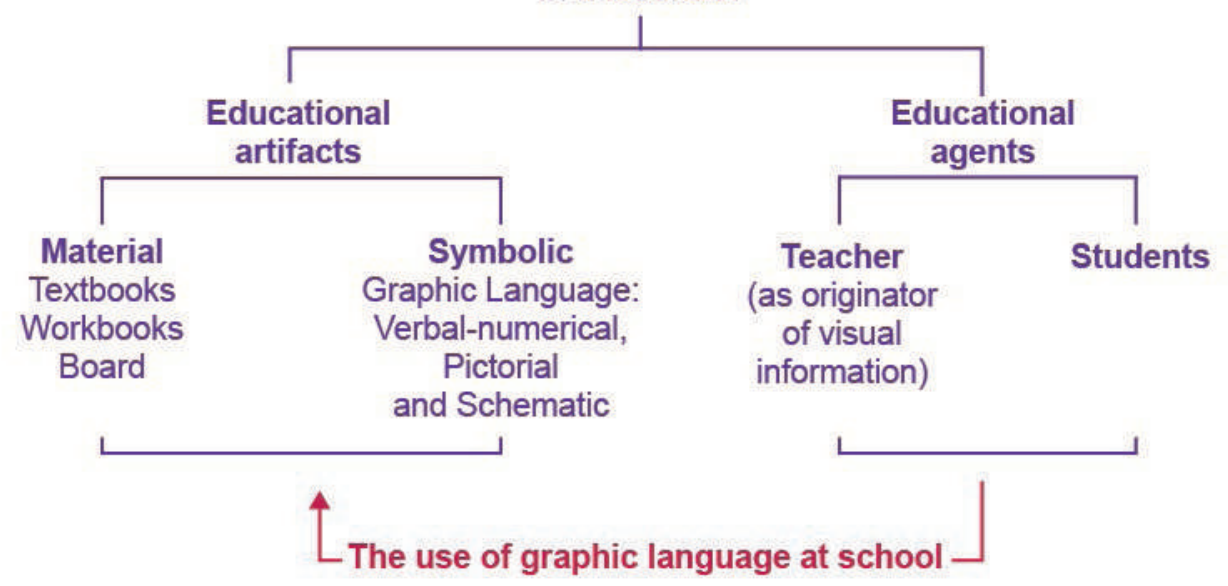

Figure 3: The study universe of Teaching Design I. (Source: the authors).

To this end, five studies were conducted, coordinated/supervised by Solange Coutinho, with the assistance of two scholarship recipients, Maria Cecília Barbosa and Bruna Andrade. The projects were:

- (1) Children's workbooks (LIPd) - Elizabelle Costa;

- (2) Textbook Illustrations: pictorial graphic language (LGP) - Verônica Freire;

- (3) The schematic graphic language of textbooks (LGE) - José Fábio Luna da Silva;

- (4) The graphic language of ephemeral artifacts: the board (LGEf) - Renata Cadena; e,

- (5) The teacher as originator of visual information (PGIV) - Maria Teresa Lopes. 
From the methodological viewpoint, the investigations adopted an eminently exploratory nature, since they sought to introduce new concepts into the primary school curriculum. As such, the approach involved transit through several areas of knowledge, and confronting policies that could integrate or obstruct the course of the investigations. Therefore, it was allied to methods derived from contemporary social and educational research. In order to undertake the search, analysis, reflection and proposal for the object of study, we adopted a qualitative approach, in order to accommodate the subjectivity of the proposed theme. This modality allowed a holistic view of the problem, which we considered a fundamental aspect of the research, since it provides the process with a dialectical character: we began the study of GL from a given problem of reality in order to attain its historical context. At this point, after becoming situated within its network of complexity - while maintaining a socially-centred viewpoint - we made a return journey, i.e., back to our starting point.

The studies included four inter-related general forms of data collection, as well as the bibliographical research, as may be observed below: (1) we experienced the teaching activities in the schools, while analysing the legislation that regulates it (LDBEN and PCNs) and examined the forms in which it was adopted within the educational environment; (2) we conducted interviews with teachers and researchers in art/education, education and design; (3) we formed a focus group with teachers, designers, illustrators and non-designers; (4) we undertook a graphic analysis and/or comprehension experiment ${ }^{12}$, summarized in Table 1. However, for each study individual protocols were created.

\begin{tabular}{|l|l|l|l|l|}
\hline Studies & $\begin{array}{l}\text { (1) Teaching } \\
\text { observation }\end{array}$ & $\begin{array}{l}\text { (2) } \\
\text { Interview }\end{array}$ & $\begin{array}{l}\text { (3) Focus } \\
\text { group }\end{array}$ & $\begin{array}{l}\text { (4) Analysis/ } \\
\text { experiment }\end{array}$ \\
\hline 1. Children's workbooks (LIPd) & & & & \\
\hline 2. Textbook Illustrations (LGP) & & & & \\
\hline $\begin{array}{l}\text { 3. The schematic GL of } \\
\text { textbooks (LGE) }\end{array}$ & & & & \\
\hline $\begin{array}{l}\text { 4. The GL of ephemeral } \\
\text { artifacts (LGEf) }\end{array}$ & & & & \\
\hline $\begin{array}{l}\text { 5. The teacher as originator of } \\
\text { visual information (PGIV) }\end{array}$ & & & & \\
\hline
\end{tabular}

Table 1: Inter-relation between the studies and data collection (Source: the authors).

${ }^{12}$ Digital photographic and video cameras were used to monitor the classes and focus group; as well as photocopies and digital reproduction to contextualize the artifacts (books, blackboards, student notebooks, etc.). 
In the investigations where teaching observation was conducted, educational activities were monitored in eight educational institutions - two were part of the municipal public sector; two from the state sector and four from the private sector. The selection criteria were as follows: (a) located in the Metropolitan Region of Recife-PE; (b) considered a large or medium-sized institution; (c) with a target public from the middle class and the working class; and (d) offering a discipline involving art or, in the absence thereof, a similar discipline. Observations occurred according to the schedule of each study (2 to 5), giving preference to the school environment, and the selected teachers were those responsible for the subjects in each specific study. The studies took place in the school classrooms.

All the interviews were semi-structured and conducted with teachers and other participants in the school routine. In certain studies, the focus group technique was used. The focus groups occurred in a specific environment for each study, and involved teachers, art/educators, educationalists, designers, illustrators and non-designers (Studies 3 and 5). The analyses were based on the protocols of each study, mainly using as a theoretical-analytical basis: Ashwin (1979); Goldsmith (1980, 1984); Mijksenaar (1997); Twyman (1979, 1981, 1982, 1985, 2002), supplemented by literature specific to each research problem.

One of the main diagnoses obtained through the research from the Teaching Design $\mathrm{I}^{13}$ project is that the use of GL in the school universe is problematic and there is little diversification. One of the causes is that teachers proved unable to use the available wide-ranging configurations and symbolizations of information as a possible educational resource for creating educational artifacts that are more appropriate for the teaching/learning process.

This difficulty arises because teacher-training courses do not provide these professionals with any form of visual formation (Coutinho, 2008, 2011; Lopes, 2009). Based on the premise that teachers use graphic artifacts on a daily basis - books, notebooks, board, computer - the inability to deal with graphic language thereby affects the visual culture of the school. Thus, there are several consequences because of this limited visual repertoire, amongst which: (a) it affects formal knowledge, by not recognising that the configuration of information is part of the content; (b) it hinders the development of pupils as originators of visual messages, which is an increasingly intense need due to the automation brought about new ICT tools; (c) the formation of visual culture as a socializing entity and associable with other disciplines remains unrecognised; and (d) there is a conflict with the imagery of reality in the outside environment of school, with which pu-

${ }_{13}$ Coutinho, 2011; Coutinho and Lopes 2011; Lopes, 2009; Costa and Coutinho, 2009; Cadena, 2010; Cadena et al., 2010, 2011. 
pils do not therefore identify or become interested in. Although these consequences may seem insignificant in the face of the complex reality of education in Brazil, in the daily routine of school, they are influential through essential postures for the performance of educational activities, such as engagement and pleasure.

We briefly present below some of the results we obtained, based on nine diagnoses ${ }^{14}$ and organized into subgroups of knowledge that indicate the assumed epistemology (Coutinho and Lopes, 2011; Lopes et al. 2012):

a) There is need to train those involved in the teaching profession, such as teachers on undergraduate courses that deal with content that is relevant to information design, since this knowledge will constantly be used during their professional life;

b) To understand graphic design as knowledge that operates when mediating the teacher/learner relationship at school, since it structures the visual messages that circulate within this universe;

c) To formulate the problematics concerning school artifacts, determining them as material agents for mediating both learning and school behaviour through: teaching, school artifacts, teacher and pupil;

d) To establish the rationale that teachers, amongst several other professionals, have enfolded into their social role the baseline condition of being a constructive agent in forming Brazilian visual culture, inasmuch as it is within their mimetic approach to graphic expression that pupils will consequently construct their own expressions;

e) To denote that ephemeral graphical language, supported by the board, is the most recurrent expression of the teaching/learning relationship and of school regulation, and that ephemeral visual messages are the basic process of this graphic expression in schools.

Teaching Design I encouraged discussion regarding information design in the human behaviour/school dimension, which affects visual culture, i.e., by analysing the collective graphic behaviour of a specific social group with a broad and basic configuration within society and not involving designers: the primary school. It is important to note that this community belongs to: school coordinators and administrators; graduate teachers; educational agents; and expressly the pupils.

At the same time however, visual school culture is dynamic, and new devices are introduced and activated on a daily basis within in this environment, the most

14 Such diagnostics are presented together with the specific objectives of Teaching Design $\mathrm{I}$ and may be found in their entirety in Coutinho, 2011. 
evident being the paradigm of adopting new technologies, the discourse of which oscillates between two poles: either attraction towards what is new, including the desire to improve practices or another concerning appropriateness and modernization, which does not consider the actors involved in education.

It is not only essential for teachers to be aware of the technological devices and their functions, but, especially of how to organize and structure information so as to achieve their position as originators of information. It was from this understanding that we formulated the Teaching Design II project, where the focus was concentrated on the formation of graduate teachers, from the perspective of information design as a tool, this time considering digital artifacts - gradually being inserted more into schools.

\section{TEACHING DESIGN II [2012/2016]}

We may infer that teachers, by appropriating knowledge on information design, are thereby susceptible to the creation of an expanding field within their training and, thus, within its visual culture. We specify those derived from verbal graphic language - typography, lettering, calligraphy; pictorial - drawing, photography, collage, comics; diagrams, maps, tables, as appointed by Teaching Design I. They make part, therefore, of contents that may assist in expanding the ways of seeing and creating messages. Allied to the intrinsic knowledge of GL, items from information design - planning, categorizing, organizing, hierarchy, forms of emphasis and visual configuration - form a set of editorial, instructional and graphical knowledge which is also a useful reference for teachers and their pupils, serving as a starting point to enhance the use of GL.

We proposed an analysis of school, based on contemporary thinking regarding the plurality of languages as a cognitive tool for establishing the teaching/ learning relationship. Our premise is that we are under the aegis of technological development, which thereby leads us to understand the revolutionary role that knowledge currently plays.

In this perspective, the set of projects that constituted Teaching Design II: the introduction of information design content in the formation of teachers aimed at proposing guidelines and parameters of content and methodologies from information design (ID) for primary education in Brazil, especially the use of graphic language (GL) in digital educational artifacts by teachers. The hypothesis is that the generation of guidelines and parameters of content and methodologies from information design directed towards the formation of teachers would assist in improving the visual culture of the educational environment.

Therefore, the following specific objectives were proposed: (a) to map the 
uses of the graphic language (GL) in digital educational artifacts as mediators of knowledge (digital board, PowerPoint, tablets); (b) to assess the weaknesses and potentialities of teachers during the process of creating and using digital mediators of knowledge; (c) to identify with designers and educationalists which information design (ID) contents and methodologies are the most useful for teacher formation; (d) to provide face-to-face (distance-learning) courses that present ID/ GL content applied to digital educational artifacts for teachers and undergraduate teachers; (e) to generate the online platform of Teaching Design for: information, management and follow-up of courses, contents, methodology and evaluation; and (f) to analyse the levels of assimilation/retention of these contents in generating new information for digital educational artifacts.

In order to undertake such a proposal, eight studies were developed, under the supervision of Solange Coutinho and Teresa Lopes. However, the project also relied on the co-supervision of other researchers, who joined the project at the time it was coming into effect and through academic experiences such as monographs, dissertations and theses, and were as follows: (1) Training the eye: information design as content for teacher formation on Brazilian degree courses - Maria Teresa Lopes; (2) the initial construction of a Matrix of Contributory Methodologies for designing pedagogical practice in the classroom - Natália Cristina Pereira Barbosa and co-supervised by Teresa Lopes; (3) The development of a new proposal for generating a methodological process in line with the needs of teachers regarding the use of visual messages in teaching materials (MetDInfo) - Natália Cristina Barbosa and co-supervised by Teresa Lopes; (4) Projected Ideas course designed for graduates on the use of Digital Slide Artifacts (ADS) - Renata Cadena; (5) An analysis of graphic artifacts produced by teachers with ICT tools in primary education - Sayonara Bittencourt and Bruna Andrade, co-supervised by Renata Cadena; (6) Graphic Training: the influence of the teacher in constructing the graphic language of pupils in basic education - Renata Cadena; (7) An analysis of the use of digital educational objects (OEDs) - Gregório Bacelar; and (8) Constructing the online platform for Teaching Design - Erika Simona Ferreira, co-supervised by Teresa Lopes. The last two studies were completed at the beginning of the next project, RIDE.

The schema in Figure 4 represents a cross-section of the Teaching Design II project, indicating the focus of the proposal centred on teachers and their formation and, in grey the material and symbolic artifacts that were the target of investigation whilst being used. 


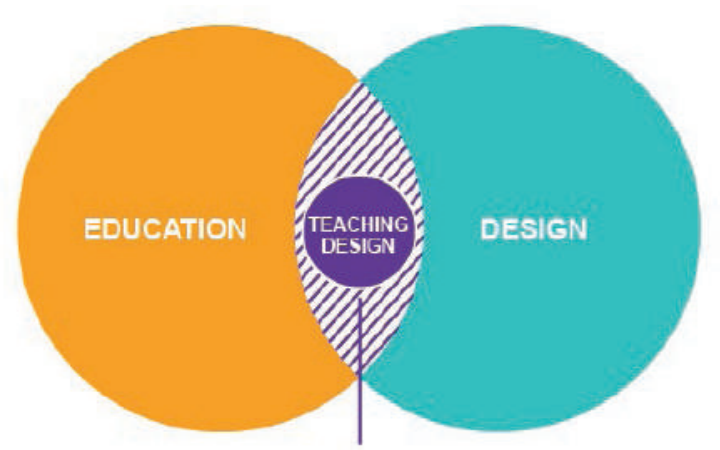

Graphic Language

in the school
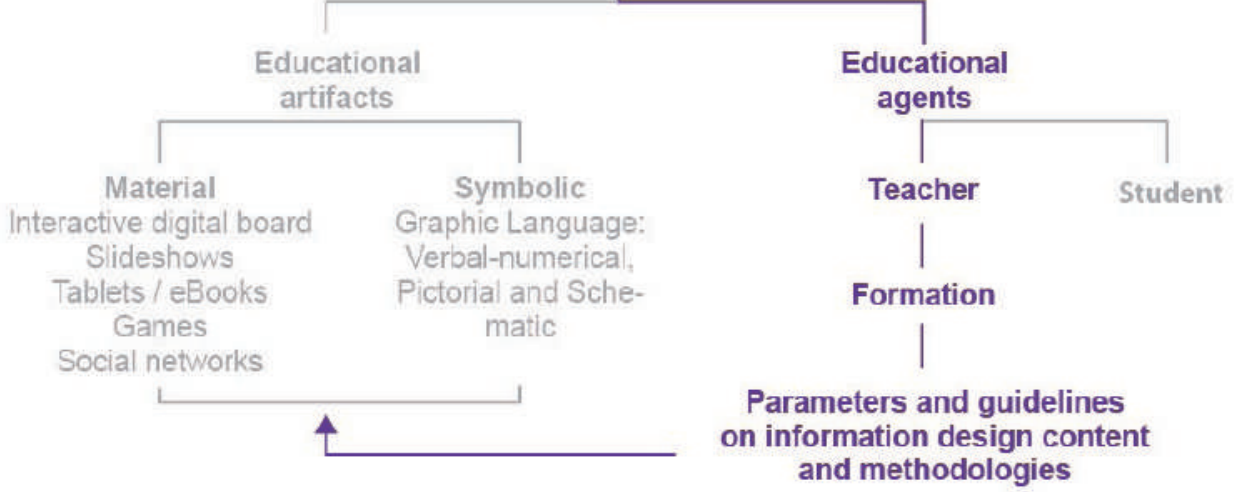

Figure 4: The universe of the study Teaching Design II. (Source: the authors).

Teaching Design I resulted in a series of diagnostics and indicated one central practical problem. In an adaptation of the schema by Booth et al. (2000), used as a methodological tool, this practical problem motivated the question for the second research, which in turn assisted in defining the problem of Teaching Design II, and in turn helped to find a possible solution, in our perspective, for creating guidelines and parameters in order to introduce ID contents and methodology into the curricular pedagogical project for graduate teachers in Brazil, expressed in Figure 5.

In order to undertake some of these possible transformations in this investigation, as with its predecessor, there was an exploratory nature, however experimental studies were also used. Thus, the approach involved transit through several areas of knowledge, also allying it to methods originating from contemporary social and educational research. 


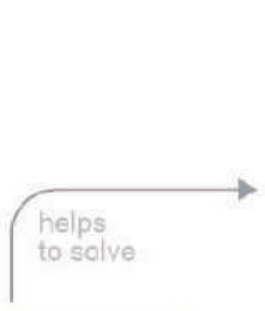

RESEARCH ANSWER

To create parameters and guidelines on information design content and methodologies for primary school teachers

\section{PRACTICAL PROBLEM}

According to the diagnosis in the Teaching Design I project, the needs of teachers in terms of graphic language in their daily lives are not considered during their training.

\section{RESEARCH PROBLEM}

To evaluate what kind of information design content and methodologies are appropriate to the needs of primary school teachers.
RESEARCH QUESTION

How may information design contribute to visual messages created, read and mediated by primary school teachers?

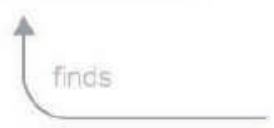

Figure 5: The Booth et al. (2000) chart applied to Teaching Design II. (Source: Coutinho, 2012).

In general terms, the research possessed a descriptive nature, located in educational practice. Five forms of general data collection were undertaken, in addition to the literature review: (1) mapping the GL activities used by teachers and undergraduates in digital educational artifacts through direct observation in the classroom; (2) analysing the process of constructing GL by non-designers through educational experiments; (3) face-to-face distance-learning courses introducing ID/GL content applied to digital educational artifacts; (4) analysing the discourse (verbal/visual) of the levels of assimilation/retention and new creations of the contents worked on during the courses; and, (5) experimental use of digital artifacts by pupils, as summarized in table $2 .^{15}$

${ }^{15}$ Digital photographic and video cameras were used to monitor the educational experiences and focus group; as well as digital reproduction to contextualize the artifacts, for each study individual protocols were established. 


\begin{tabular}{|c|c|c|c|c|c|}
\hline Studies & $\begin{array}{l}\text { (1) } \\
\text { Mapping } \\
\text { digital GL }\end{array}$ & $\begin{array}{l}\text { (2) } \\
\text { Analysing } \\
\text { the } \\
\text { process }\end{array}$ & $\begin{array}{l}\text { (3) } \\
\text { Courses }\end{array}$ & $\begin{array}{l}\text { (4) } \\
\text { Analysing } \\
\text { the } \\
\text { discourse }\end{array}$ & $\begin{array}{l}\text { (5) } \\
\text { Experimenting }\end{array}$ \\
\hline $\begin{array}{l}\text { 1. Training the eye } \\
\text { through information } \\
\text { design. }\end{array}$ & & & & & \\
\hline $\begin{array}{l}\text { 2. Matrix of } \\
\text { Contributory } \\
\text { Methodologies in } \\
\text { Design }\end{array}$ & & & & & \\
\hline $\begin{array}{l}\text { 3. MetDInfo } \\
\text { methodology of } \\
\text { Infodesign for the } \\
\text { formation of teachers }\end{array}$ & & & & & \\
\hline $\begin{array}{l}\text { 4. Digital Slide } \\
\text { Artifacts - ADS }\end{array}$ & & & & & \\
\hline $\begin{array}{l}\text { 5. Graphic artifacts } \\
\text { created by teachers } \\
\text { with ICT }\end{array}$ & & & & & \\
\hline 6. Graphic Training & & & & & \\
\hline $\begin{array}{l}\text { 7. Digital Educational } \\
\text { Objects }\end{array}$ & & & & & \\
\hline $\begin{array}{l}\text { 8. Online platform for } \\
\text { Teaching Design }\end{array}$ & & & & & \\
\hline
\end{tabular}

Table 2: Forms of data collection from the studies. (Source: the authors).

We observed that the familiarity of teachers and undergraduates with the artifacts is a relevant factor regarding the manner with which they choose them for school practices and that, due to the unsystematic character of teacher formation in creating educational resources, these practices remain based on empirical professional experience. In order to create a formative experience, the inclusion of discussions on the design of artifacts during teacher formation courses was one way of dealing with the aspect of being a creator. This allowed teachers to become more comfortable and autonomous in performing this dimension of their professional activities, and in approaching the contemporary languages and possibilities that pupils experience and demand both in and out of school (Cadena and Coutinho, 2016). 
At the same time, by means of a survey, it was possible to reinforce the need for schools to keep abreast of new graphic languages that increasingly appear in educational artifacts, and which are extremely important for ensuring that pupils assimilate content appropriately, accompanied at the same time, through technologies that conveys this diversity of visual messages, the intrinsic social changes.

Research in the field of epistemology (design and education) demonstrate the close relationship between graphic language and education in that design contents are present not only in educational artifacts, but in every school environment. We may infer therefore, that it is increasingly more necessary, 'for teachers as mediator agents of knowledge, to have a basic understanding of this relationship thereby enabling them to pass on the contents more effectively to their pupils/students, and also to put them in contact with every visual potential that the new pedagogical resources are able to generate' (Barbosa, 2015, p.11).

As a response, we obtained the following diagnoses from the constituent surveys of the Teaching Design II Project (Andrade et al., 2012; Lopes et al., 2012; Lopes 2014; Cadena, 2014; Barbosa, 2015; Bittencourt et al., 2015; Cadena and Coutinho, 2016), and discovered that:

a) Teachers display a social disposition ${ }^{16}$ towards the field of design, because they recognize design not only in its visual aspects, but also as a creative process;

b) There is a need for an approximation to occur between design as knowledge and the teacher, 'in order to seek out an epistemological dialogue so that right from the time of their formation period, teachers may obtain an understanding of themselves as an active subject, as a communicator, developing and expanding graphic and visual thoughts' (Lopes, 2009; p. 42);

c) Actions are needed in the school environment to train and monitor schools with regard to technological changes related to communication and information;

d) Design contributes to ICT training, since teachers already understand that graphic design is a decisive component in the use of these technologies, and is able to help them understand and manage the appropriate production of visual messages present in educational artifacts;

e) Design contents must be incorporated into teacher formation on degree courses, given the success rate of the experiments with MetDInfo (Barbosa,

${ }^{16}$ We adopt the perspective of Social Disposition from the Dispositional Theory belonging to the field of sociology that relates to the Action Theory, herein employed from the perspective of Lahire (2004). 
2015) during the Design for Teachers course developed and taught by Lopes (2014), and the Projected Ideas course that examined the use of digital slide presentations by Cadena (2014).

During the concluding phase of Teaching Design II, the authors of this article formulated a number of reflections on the set of results from Teaching Design I and II, which recommended the adoption of actions that promoted the construction of a new field of knowledge, herein termed Design/Education. Further motivated by more effective actions and by the institutional internationalised relations of the Research Group in Information Design at UFPE ${ }^{17}$, they decided to create RIDE as a network, project and research group, as set out below.

\section{RIDE - THE INTERNATIONAL DESIGN/EDUCATION NETWORK [2016/2020]}

Coutinho and Lopes (2011) argue that when the fields of design and education are brought together we architect the construction of a social perspective, centred on the formulation of design principles that contribute to educational practices. Understanding teachers as active actors in the field of communication and visual expression presupposes a breakdown of certain pre-established paradigms through the role they play in society. There is a need to break with the recurrent idea of public education policies, and even certain academic epistemologies, that within the methodological universe of teachers and their practices there is a prism whose vertex is verbal language (written and spoken) through which a major part of their formation knowledge is dissipated and focused.

The required paradigm shift reflects the need to discuss design through the prism of its logic, of its actions and practices, and of its discourses ${ }^{18}$ and methods, thereby moving away from the idea of it being an educational support (as mediator), to that of being an action intrinsic to education (as agent). This debate arouses ontological and epistemological questions to the field, ${ }^{19}$ inherent to the social transformations in which design is the protagonist, whereby its largescale action

17 In 2013, Maria Teresa Lopes, participated in a sandwich doctorate course at Université Paris 1 - Pantheon Sorbonne, co-supervised by Prof. Berrnard Darras.

18 See Foucault (2013). The order of discourse: inaugural lecture at the Collège de France, on December 2nd, 1970.

19 Field, proposed by Bourdieu (2012) is a theory of sociology, which is expressed as a symbolic space, where agents determine, fight, validate and legitimize representations and negotiations based on symbolic power relations, where signs and meanings determine belongings, languages, codes and values (Bourdieu, 2012, p. 9). 
is an intervention within our material and symbolic culture.

In order to structure RIDE, we have looked to the emancipatory actions of the field of education and to the discourses, practices, actions and methods brought by the field of design. Thus, the network is based on two fundamentals from the field of design/education: (1) formation [or actions of formation], and (2) the production of educational devices. Linked to these fundamentals, the network will also contain four dimensions ${ }^{20}$ : (a) discourse; (b) agents; (c) agencement; (d) setting.

In the system of meanings that RIDE assumes, we have adopted the term 'device', in accordance with the cumulative dimension cited by Lopes (2014, p. 286 ) in which a device is discourse (from Foucault's perspective) as well as action and intentionality (from Argamben's perspective) while it also remains an artifact (from Darras' perspective). In other words, an educational device presupposes the existence of a given artifact, which in turn is formulated with a certain intention, onto which a discourse has been constructed.

Implicit in the field of design/education, as a practical problem of the resear$\mathrm{ch}$, is the practice of the information agencements in the Brazilian education environment, which thereby motivates the research question, "how do agencements in the field of design/education contribute to the Brazilian education environment?" From this question, the research problem is formulated and constitutes the very definition of the field of design/education, from the actions of formation and the production of educational devices. The aim, therefore, is to propose the creation of RIDE in order to discuss and suggest responses to the challenges posed within the scenario of formation in design. This methodological tool - the adapted schema by Booth et al. (2000) is presented in Figure 6.

${ }^{20}$ The term 'discourse' is attributed to the intellectual synthesis linking speech and thought; 'agent' presupposes an action in the field of design/education (DE); 'agency' refers to actions, events, phenomena, in the same field; 'setting' is understood as visual and object landscapes. 


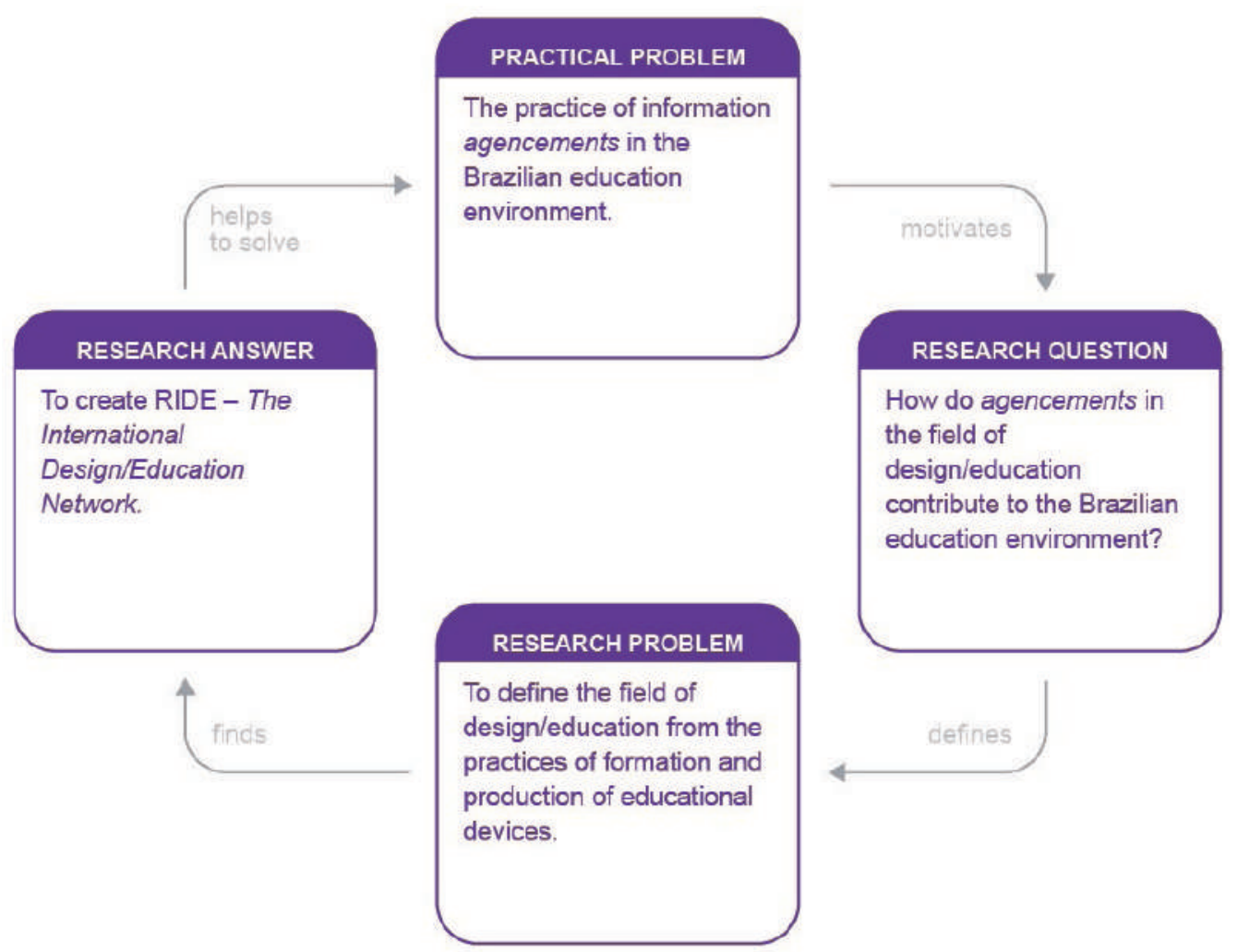

Figure 6: Chart proposed by Booth et al. (2000) applied to RIDE (Source: Coutinho et al. 2016).

At the intersection of the RIDE network, there are certain specificities, inherent to their respective questions of practical and/or theoretical research, founded upon three grid axes of fundamentals, and consisting of fourteen actions/projects.

The first axis focuses on the fundamentals of formative action, amongst which are included the following actions/projects: (1) Teaching Design [TD], aimed at generating guidelines and parameters in information design (ID) for the formation of primary school teachers in Brazil; (2) the formation of non-specialists $^{21}$ [FNS], consisting of formative actions for non-designers, through training the eye with the support of design content and logic; (3) Agents of Innovation [AI], which outlines the fundamental characteristics that enable teachers as agents

21 Non-specialists', in the area of research, are those professionals who are not designers. 
of innovation and design as knowledge capable of potentializing these qualities; and (4) the Model School [MS], in which the non-linear and innovative pedagogical models of training pupils will be investigated, discussing school-society-technology incompatibility and, as a consequence, in Illich's (1976) perspective, the process of institutionalization across the world.

The second axis presents projects involving the fundamentals of educational devices: (1) Heuristics and Methodologies [HandM], containing as studies, the question of the imagery and verbal efficiency of information in educational devices proposing new methodological paths, whilst at the same developing heuristics for their production by specialists for primary education; (2) Digital Educational Objects (DEOs) (already completed), also recognized as Learning Objects [LO], aiming to evaluate the impact on the performance of high school students using these objects in devices such as hyperbooks versus those using the printed book. These two studies evaluated the reception or the agencements of these devices by users; and (3) ReDE (Device), this action involved creating the International Design/Education Network environment to support all the actions of the researchers as well as facilitating the actions of training and the production of educational devices (graphic project already executed, but remains offline, in the testing phase).

Finally, those projects that aim to discuss the fundamentals of formation associated with those of educational devices so that they may collaborate to modify the institutionalized logic of agents that produce a broad typology of educational devices - teachers, coordinators, school administrators, designers, illustrators, content writers, designers, to name a few. To that end, four activities are in progress: (1) Formation with Devices [FwD], forming new modes of formation for teachers through educational devices based on design actions; (2) A convivial viewpoint $[\mathrm{CV}]$, in which information design has been discussed as a convivial learning tool, starting with the philosophy of Ivan Illich; (3) The RIDE paradigm, which aims to establish the international network, solidify the field of design/ education, while at the same time, intending to formulate the new paradigm of design as a support for design as a transforming and emancipatory action of agents, environment, discourse and educational agencements; and (4) recently included in this network is the formation of specialists [FS], i.e., graphic language content, such as drawing, typography and calligraphy for design students.

Therefore, the object of study are the actions of formation and educational devices for specialists and non-specialists in design/education. In order to achieve its general objective, the following specific objectives were formulated: (1) to define the relationship between design and education in the field of design; (2) to map actions and key actors in the relationship between design and education; (3) to propose guidelines for formation in Design/Education; (4) to propose guideli- 
nes for the production of educational devices; (5) to provide formation for specialists and non-specialists in Design/Education (Figure 7).

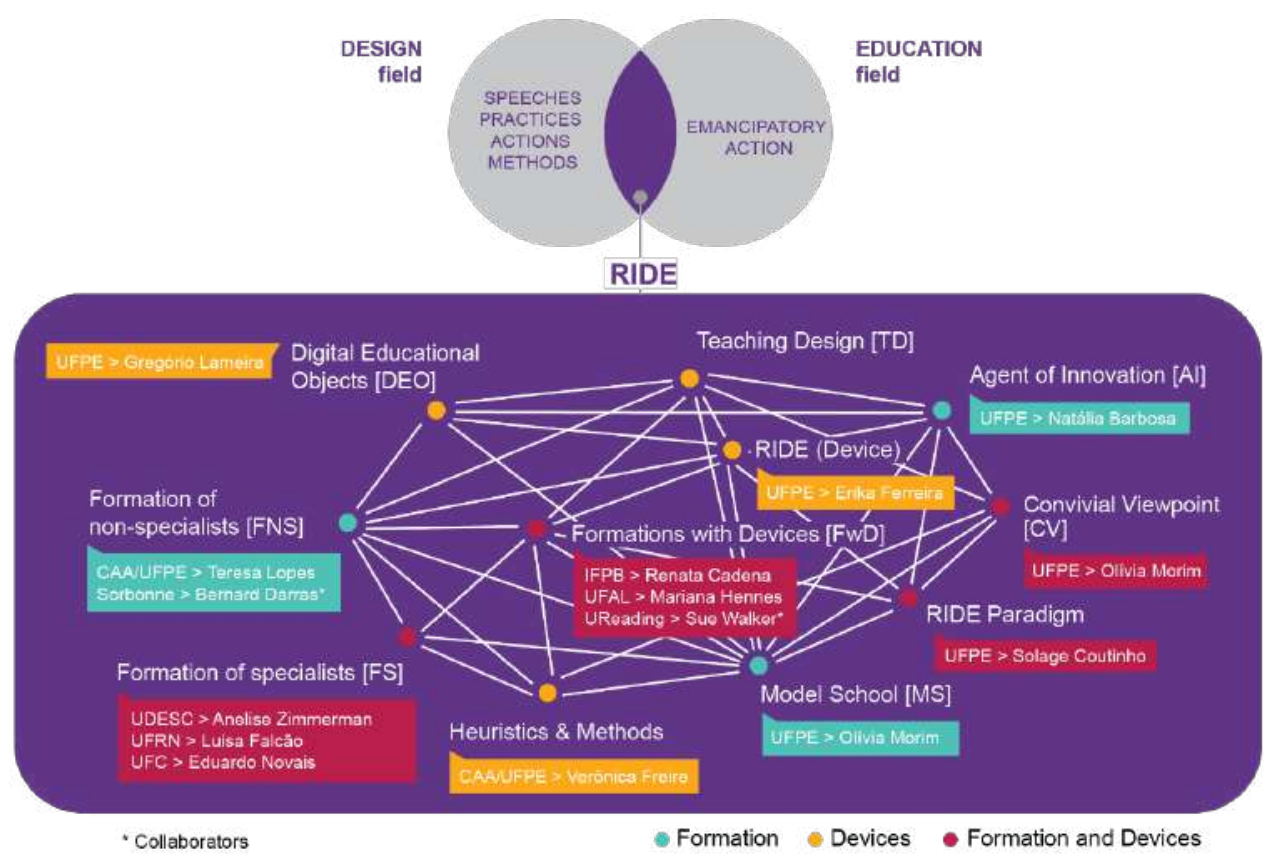

Figure 7: The structure of RIDE. An intersection between the fields of design and education representing the action/projects that are/will be developed as a chain, comprising three large grid axes of fundamentals: Formation; Devices; and Formation and Devices. (Source: the authors).

In this respect, the network metaphors have served to describe a series of phenomena or relations of reality. They have become a new social morphology of our societies and the diffusion of their logic has substantially modified the operation and the results of the processes of production, experience, power and culture (Rossetti-Ferreira, et al., 2008; p.152). For RIDE, the definition that has most contributed to our network concept, from the perspective of the Network of Meanings, is defined by the authors, as:

There is a dialogue between the network and the theoretical and methodological references that support the systemic, complex and interdependent nature of the processes under investigation. Referring to human development with the use of this dialogue signifies incorporating, into the research, a viewpoint that contemplates otherness and that always considers its character situated in historical-cultural contexts (Rossetti-Ferreira, et al., 2008; p.150). 
Therefore, the transformation of Teaching Design into RIDE (Design/Education) signifies an update in its methodological process by considering the social complexity of our contemporaneity and of the new social dispositions for implicit learning. In this perspective, the importance of the network metaphor lies in the 'idea of interlacing relationships, in the multiplicity of interconnecting threads in multidimensional combinations' (Rossetti-Ferreira, et al., 2008; p.152).

Thus, the projects and researchers that integrate RIDE - linked by values, objectives and fields of common meanings - do not develop in isolation, they are always interrelated and with collaborative practices, functioning as supports that guarantee the integrity of the whole. Each study has its own space of experience, outreaches and agencements of symbolic power and thereby through the process of exchanging knowledge establishes the design/education field of action as reality.

Here, it should be emphasized that the information flow within RIDE with which it becomes a field of academic knowledge as well as its pragmatic measure, provide a free and equal performance for all its members, thereby organising equal proportions of responsible, collaborative research. Its operation is in a state of centrifugal expansion (where each member is a nucleus of individual knowledge), which in turn demands greater effort from the associated researchers. This radial relationship evokes an open system in a state of equilibrium, providing a dynamic environment in which innovation may flow, design may act and where the outreach of RIDE is glocal.

Due to the diversity of projects, data collection will take place through various procedures, supported by qualitative, quantitative and qualitative-quantitative analyses (Table 3). Thus, RIDE will function as an incubator of academic projects supported by the UFPE, where its researchers have the opportunity to develop their studies helped by the interaction of a network of professionals and their respective knowledge, as well as investments in technology and physical structure. Thus, the incubated research studies will have a greater opportunity to grow and expand, especially in the initial phases, where there is generally a need for greater supervision. However, these projects, even after being completed and/ or matured, would continue to be part of RIDE, by archiving and transmitting the knowledge developed by their researchers, thus acting as a form of support for future projects. Each of the dimensions (discourse, agents, environment and agencements) will be the object of specific studies, each with their own objectives, but based on the same paradigm, constituting the creation of RIDE - the International Design/Education Network. 


\begin{tabular}{|c|c|c|c|c|c|}
\hline Responsible & Fundamentals & Dimensions & Appro & ches & Subject \\
\hline & & & Qual. & Quant. & \\
\hline Solange Coutinho & $\begin{array}{l}\text { Formation/ } \\
\text { Device }\end{array}$ & Agencement & & & $\begin{array}{l}\text { [TD] Teaching } \\
\text { Design }\end{array}$ \\
\hline Teresa Lopes & Formation & Discourse & & & $\begin{array}{l}\text { [FNS] Formation } \\
\text { of non-specialists }\end{array}$ \\
\hline Natália Barbosa & Formation & Agents & & & $\begin{array}{l}\text { [Al] Agents of } \\
\text { Innovation }\end{array}$ \\
\hline Olívia Morim & Formation & Environment & & & $\begin{array}{l}\text { [MS] Model } \\
\text { School }\end{array}$ \\
\hline Verônica Freire & Device & Agencement & & & $\begin{array}{l}{[\text { HandM] }} \\
\text { Heuristics and } \\
\text { Methodologies }\end{array}$ \\
\hline Gregório Bacelar & Device & Agencement & & & $\begin{array}{l}\text { [DEO] Digital } \\
\text { Educational } \\
\text { Objects }\end{array}$ \\
\hline Erika Simona & Device & Agencement & & & $\begin{array}{l}{[\mathrm{REDE}] \mathrm{D} / \mathrm{E}} \\
\text { Device Network }\end{array}$ \\
\hline Olívia Morim & $\begin{array}{l}\text { Formation/ } \\
\text { Device }\end{array}$ & Environment & & & $\begin{array}{l}{[\mathrm{CV}] \text { Convivial }} \\
\text { Viewpoint }\end{array}$ \\
\hline Renata Cadena & $\begin{array}{l}\text { Formation/ } \\
\text { Device }\end{array}$ & Agencement & & & $\begin{array}{l}\text { [FwD] Formation } \\
\text { with Devices }\end{array}$ \\
\hline Mariana Hennes & $\begin{array}{l}\text { Formation/ } \\
\text { Device }\end{array}$ & Agencement & & & $\begin{array}{l}\text { [FwD] Formation } \\
\text { with Devices }\end{array}$ \\
\hline Solange Coutinho & $\begin{array}{l}\text { Formation/ } \\
\text { Device }\end{array}$ & Agencement & & & $\begin{array}{l}{[\mathrm{RIDE}]} \\
\text { International D/E } \\
\text { Network }\end{array}$ \\
\hline $\begin{array}{l}\text { Anelise } \\
\text { Zimmerman }\end{array}$ & $\begin{array}{l}\text { Formation/ } \\
\text { Device }\end{array}$ & Agencement & & & $\begin{array}{l}\text { [FD] Formation > } \\
\text { drawing }\end{array}$ \\
\hline Eduardo Novais & $\begin{array}{l}\text { Formation/ } \\
\text { Device }\end{array}$ & Agencement & & & $\begin{array}{l}\text { [FC] Formation > } \\
\text { calligraphy }\end{array}$ \\
\hline Luiza Falcão & $\begin{array}{l}\text { Formation/ } \\
\text { Device }\end{array}$ & Agents & & & $\begin{array}{l}{[\mathrm{FT}] \text { Formation }} \\
\text { Model > } \\
\text { typography }\end{array}$ \\
\hline
\end{tabular}

Table 3: The correlation between the ten studies connected to RIDE, those responsible for each, the guiding fundamentals, and dimension of action, research approaches and subjects treated. (Source: the authors). 
The expected results we would propose are: (1) to establish the Design/Education field; (2) to generate the network device for linking the agents and contents produced; (3) to consolidate the Design/Education network; (4) to hold the first Design/Education conference; (5) to hold the first international Design/Education event; (6) to encourage the involvement of visiting teachers; 7 ) to encourage the mission of researchers to other countries [events/studies]; (8) to produce international publications; and, (9) to create the Brazilian Society of Design/Education.

\section{SOME PRELIMINARY CONSIDERATIONS}

With the main aim of aiding the construction of an educational environment conducive to stimulating and developing the cognitive potentialities that a visual channel (Twyman 1979, 2002) incites, the intention of RIDE, through the action of design, is to stimulate the relationship that it develops with graphic expressions of language, either images, texts or schemas, and the various levels of associated visual perception, thereby providing the potential for "training the eye", as proposed by Lopes (2014).

The concept of Training the Eye through design, as proposed by the author, offers a new way of perceiving the world to those who participate in this process, where the focus is on the visual discourse of the devices that organize their world. The objective is to help them understand and use the marks of meaning presented in the appearance of objects, in their subjective, objective, and contextual discourse, the purpose of which is to create a graded description of the distinctive expressions of this object, both in itself and in relation to others, so that it may thereby educate itself and others. It involves isolating the nucleus that individualizes this manner of formation depending on a particular group, which, in this case would be information design. This nucleus has the purpose of displacing the manner of formation, hitherto subject to the reality of graphic communication, and moves it into the field of symbolic power for the dimension of the individual, i.e., emancipation through developing the skills and abilities to author the production of devices (in this case, educational) and the possession of visual discourse that removes it from a position of submission thanks to a certain degree, to the field of design. However, it is important to note that we understand that information design exists at school, and that teachers do in fact make use of the graphic language dimension, although they do not recognise it as such.

Lopes (2014) believes that the term discourse is attributed to the intellectual synthesis between speech and thought, which compromises the act of creating with the cultural values of the individual who utters it, and yet made visible mainly through the abilities of those handling the fundamentals of graphic language. She also adds that Training the Eye aims to assist this individual in minimizing 
the problematics that occur between the discourse of speech and the discourse of graphic representation, with special focus on the educational environment.

Linked to this understanding, in order to broaden the basis of an educational episteme, we have adopted presuppositions from psychology, where the guiding principle will be the social interactionist theory of Lev Vygotsky (2009), from which we will initially focus on one important concept: symbolic mediation, i.e., the understanding that human beings relate to society through the intermediation proposed by signs, starting from the assertion that man deals with his daily tasks through the use of instruments. Therefore, the concept of symbolic mediation is based on the fact that currently, producer/consumer agents of information use instruments that have been produced through a process involving thoughts on design.

The roles of the student, the teacher, the educational administrators, and the definition of knowledge itself are being reconsidered, in that as portable visual devices, and expressly in the way they are used - both through software and social networks - they have invaded traditional educational spaces, offering new cognitive possibilities. This does not only concern new devices, but also new forms related to knowledge and, therefore, new forms for creating interdisciplinary projects, besides new modalities of education mediated by technology.

Our concern is centred on the use that is made of the language/information generated in educational devices, both the traditional and the new.

We take as examples the investigations conducted by Cadena (2010) and Bittencourt et al. (2015), focused on the use of graphic language (GL) on both the board and the digital board. Cadena (op. cit.) assessed the use of GL on the board, termed Ephemeral Graphic Language (EGL), which enabled her to monitor visual messages produced by primary school teachers. Although these compositions are widely used during classes, teachers have been hesitant in diversifying their content, both form and function, often insisting on the use of ineffective models and on less reflective, mechanical activities.

The aim of Bittencourt et al. (2015), in turn, was to investigate whether teachers used the same GL and the same functions with both the digital board and the traditional board. The investigation was undertaken in both public and private schools in the city of Recife. However, it was verified that although the digital board is a technological apparatus with great potential for institutions, it is relatively underused in the Metropolitan Region of Recife due to the budgetary confines involved in its acquisition, technical training and maintenance. In both public and private schools, the structural apparatus was a factor that strongly influenced the relationship of teachers with the device, discouraging them from using it. Associated to this, despite their formation, it was observed that teachers 
generally use those software to which they are most accustomed in order to produce classroom content. Thus, the interactive aspect of the digital board, which is the main differential in relation to slide projection and the traditional board, becomes lost.

Through the given arguments, it may be surmised that the problem is not centred on the objects or the technologies, but rather on the lack of basic knowledge or information regarding the practice of teaching, together with those originating from the field of design. Thus, discounting any idealized view of everyday school life - since we recognize that teachers have to deal with various difficulties, such as lack of time, resources and motivation to carry out their pedagogical activities - we may state, however, that the two studies stand as an example of how the available classroom resources are extremely underused.

It is a fact that society is rapidly migrating from a cognitive relationship polarized in text and speech to one that is more varied, in which the image is naturally incorporated as a constructive entity of communication, information and instruction for learning. For this, it is important to discuss the formation process, which includes, for example, the dimension of design, drawing and cinema, according to a classification that specifies the types of knowledge that people may move towards, compelled by a continuous formation system, so that education does not just become an exclusive process. It should rather be a contemporary process of constructing forms of knowledge that indeed act towards formation and transformation, thus enabling people to become part the complexity and plurality that shapes the spirit of the postmodern contemporary subject.

With the course that our work has taken so far, we have sought to provide a brief overview of the context of RIDE, based on the research that preceded it; its objectives; its justification for the area of design; some preliminary concepts and the philosophical and intellectual conditions it has taken on. The outline of this scenario is of importance to the argument that design, as a field of theoretical and practical narratives, may contribute to contemporary learning, acting as an intrinsic intellectual activity for educational devices and in the formation of non-specialists in the field, thereby promoting improvement in the mediation of knowledge, increasingly more specific and at the same time more complex.

\section{REFERENCES}

Andrade, B.; Cadena, R.A; Coutinho, S.G. 2012. Análise dos artefatos gráficos elaborados com ferramentas de TIC no Ensino Fundamental Brasileiro. In: Anais do X Congresso Brasileiro de Pesquisa e Desenvolvimento em Design. PandD Design 2012. São Luis: EDUFMA.

Ashwin, C. 1979. The ingredients of style in contemporary illustration: a case study. In- 
formation Design Journal, v.1, n.1, p.51-67.

Barbosa, N.C.P. 2015. Design e escola: o professor como um agente para inovação no ensino fundamental e médio. Monografia de graduação não publicada. Recife: Departamento de Design, UFPE.

Bittencourt, S.; Cadena, R.A; Coutinho, S.G. 2015. Análise do uso da lousa digital na educação básica do Recife. In: Proceedings of the 7th Information Design International Conference I CIDI 2015. São Paulo: Blucher Proceedings, v.2, n.2, p.1523-1527.

Booth, W.C.; Colomb, G.G.; Williams, J.M. 2000. A arte da pesquisa. Tradução Henrique A. Rego Monteiro. $1^{\mathrm{a} e d}$. São Paulo: Martins Fontes.

Bourdieu, P. 2012. O poder simbólico. Rio de Janeiro: Bertrand Brasil.

Cadena, R.A. 2014. Aperfeiçoando projeções: Experiências de formações em design de apresentações digitais de slides (ADS) com estudantes de licenciatura de Pernambuco. Dissertação de mestrado não publicada. Recife: Programa de Pós-Graduação em Design, UFPE.

2010. Linguagem gráfica efêmera: uma investigação acerca das mensagens produzidas no quadro em escolas do Recife de ensino fundamental. Monografia de graduação não publicada. Recife: Departamento de Design, UFPE.

Coutinho, S.G. 2016. O professor e a elaboração de materiais didáticos gráficos para a visualização coletiva de informações. In: Anais do V Simpósio sobre o Livro Didático de Língua Materna e Língua Estrangeira and do IV Simpósio sobre Materiais e Recursos Didáticos. São Paulo: Blucher, Proceedings v.2, n.6, p.1-10.

Coutinho, S.G.; Lopes, M.T. 2011. A linguagem gráfica efêmera e o design no ensino fundamental brasileiro. Infodesign (SBDI. Online). São Paulo: Sociedade Brasileira de Design da Informação, v.8, n.3, p.1-11.

Coutinho, S.G.; Lopes, M.T. 2010. O Design da Informação na escola: uma investigação introdutória acerca do uso da lousa no terceiro ano do ensino fundamental. In: Anais do $9^{\circ}$ Congresso Brasileiro de Pesquisa e Desenvolvimento em Design PandD DESIGN 2010. São Paulo: AEND|Brasil, 2010.

Costa, E.P.; Coutinho, S.G. 2009. A cultura visual paralela: o design do livro infantil para-didático. In: Anais do 4 Congresso Internacional de Design da Informação. Rio de Janeiro: SBDI. Disponível em http://www.sbdi.org.br/congresso.

Coutinho, S.G. 2012. Ensina Design 2: A introdução de conteúdos de Design da Informação na formação dos professores das Licenciaturas. Projeto de Pesquisa aprovado pelo CNPq, não publicado. Recife: Departamento de Design, UFPE, 34p.

2011. Ensina Design: A introdução de conteúdos de Design Gráfico no currículo do Ensino Fundamental Brasileiro. Relatório Final apresentado ao CNPq, não publicado. Recife: UFPE, 44p.

2008. Ensina Design: A introdução de conteúdos de Design Gráfico no currículo do Ensino Fundamental Brasileiro. Projeto de Pesquisa aprovado pelo CNPq, não publicado. Recife: Departamento de Design, UFPE, 31p. 
2006. Design da Informação para Educação. Infodesign, v.3, p.52-63.

Lopes, M.T.; Barbosa, N.C.P.: Cadena, R.A. 2016. RIDE - Rede Internacional de Design/Educação. Projeto de Pesquisa aprovado pelo CNPq, não publicado. Recife: Departamento de Design, UFPE, 43p.

Lopes, M.T. 2011. Design para educação: uma possível contribuição para o ensino fundamental brasileiro. In: Marcos Braga (Org.) Papel social do design gráfico. São Paulo: Editora SENAC, p.137-162.

Freire, V.E.C. 2007a. Information Design for Education: an evaluation of the use of images in young children's workbooks In: Proceedings of the International InSEA Congress 2007, Art Education Research and Development. Heidelberg: Pädagogische Hochschule Heidelberg, 2007.

Coutinho and Freire, V.E.C. 2007b. Design para Educação: uma avaliação do uso da imagem nos livros infantis de Língua Portuguesa. In: Cleomar Rocha (Org.), Arte: limites e contaminações - Anais do $15^{\circ}$ Encontro Nacional da ANPAP (2006). Salvador: ANPAP/UNIFACS, vol.II, p.245-254.

Silva, J.F.L. 2007. Linguagem visual em livros didáticos infantis. In: Cleomar Rocha (Org.), Arte: limites e contaminações - Anais do $15^{\circ}$ Encontro Nacional da ANPAP (2006). Salvador: ANPAP/UNIFACS, vol.II, p.255-265.

Dondis, D.A. 1997. Sintaxe da linguagem Visual. Tradução de Jefferson Luiz Camargo. 2.ed. São Paulo: Martins Fontes.

Fabris, G. 1973. Fundamentos del proyecto gráfico. 2.ed. Barcelona: Dom Bosco.

Freire, V.E.C. 2005. A função semântica de imagens em livro didático infantil de Língua Portuguesa. Monografia de graduação não publicada. Recife: Departamento de Design, UFPE.

Fontoura, A.M. 2002. EdaDe: a educação de crianças e jovens através do design. Florianópolis. Tese de doutorado não publicada. Programa de Pós-Graduação em Engenharia de Produção. Florianópolis: Universidade Federal de Santa Catarina - UFSC, 337p.

Foucault, M. 2013. A ordem do discurso: aula inaugural no Collège de France, pronunciada em 2 dezembro de 1970/Michael Foucault, tradução Laura Fraga de Almeida Sampaio - $23^{a}$ ed., São Paulo: Edições Loyola.

Goldshmith, E. 1984. Research into illustration: an approach and a review. Cambridge: Cambridge University Press.

Goldshimth, E. 1980. Comprehensibility of illustration: an analytical model. Information Design Journal, v.1, p. 204-213.

Illich, I. 1976. A convivencialidade. Tradução: Arsénio Mota. Lisboa: Publicações Europa-América.

Lahire, B. 2004. Retratos Sociológicos: Disposições e Variações individuais. Porto Alegre: Artmed.

Lopes, M.T. 2014. Uma formação do olhar: o design da informação como conteúdo formador dos professores das licenciaturas brasileiras. Tese de doutorado não publicada. 
Recife: Programa de Pós-Graduação em Design, UFPE, 499p. 2009. A linguagem gráfica na educação brasileira: um estudo para a sua inserção na formação dos professores das licenciaturas. Dissertação de mestrado não publicada. Recife: Programa de Pós-Graduação em Design, UFPE, 237p.

Coutinho, S.G.; Barbosa, N.C.P. 2012. Metodologia de design e a prática pedagógica na sala de aula: a construção inicial de uma Matriz de Metodologias Contributivas, 2012. In: Anais do X Congresso Brasileiro de Pesquisa e Desenvolvimento em Design - PandD Design 2012. São Luis: EDUFMA.

Mijksenaar, P. 1997. Visual function. An introduction to informational design. Nova York: Princeton Architectural Press.

Morim, O.M. 2007. Design e Educação: uma discussão sobre a introdução de noções de design gráfico como uma atividade no currículo de artes do Ensino Fundamental Brasileiro e uma proposta inicial de conteúdos para essa atividade. Monografia de graduação não publicada. Recife: Departamento de Design (UFPE).

Rosseti-Ferreira, M.C.; Amorim, K.S.; Soares-Silva, A.P.; Oliveira, Z.M.R. 2008. Desafios metodológicos na perspectiva da rede de significações. Cadernos de Pesquisa, FFCLRP/US, São Paulo, v.38, n.133, p.147-170, jan./abr.

Silva, J.F.L.; Coutinho, S.G. 2010. Esquemas gráficos para informar: a linguagem gráfica esquemática na produção e utilização de livros didáticos infantis na cidade do Recife. In: Anais do $9^{\circ}$ Congresso Brasileiro de Pesquisa e Desenvolvimento em Design - PandD DESIGN 2010. São Paulo: AEND|Brasil.

Twyman, M.L. 1979. A schema for the study of graphic language. In: Processing of visible language. Paul A. Kolers, Merald E. Wrolstad and Herman Bouma (Org.). Nova York and Londres: Plenum Press, v.1, p.117-150.

1981. Articulating graphic language: a historical perspective in Merald E. Wrolstad and Dennis F. Fisher (Eds.),Towards a new understanding of literacy. New York: Praeger Special Studies, p.181-251.

1982. The graphic presentation of language. Information Design Journal, v.3, n.1, p.2-22.

1985. Using pictorial language: a discussion of the dimensions in Thomas $\mathrm{M}$. Dufty and Robert Waller (Eds.) Designing usable text. Orlando, Florida: Academic Press, p.245-312.

2002. Further thoughts on a schema for describing graphic language. In: Proceedings da 1st Internacional Conference on Typography and Visual Communication History, Theory, Education. June 2002, Thessaloniki, Greece.

Vanderlei, P. B.; Coutinho, S. G. 2003. Análise gráfica das mensagens visuais nas escolas do Recife. Anais do 3o Encontro Internacional de Arte e Tecnologia e 12o Encontro Nacional da ANPAP - Associação Nacional de Pesquisadores em Artes Plásticas: a arte pesquisa. Brasília, DF: ANPAP/UNB. CR-ROM.

Vygotsky, L.S. 2009. A construção do pensamento e da linguagem. São Paulo: Martins Fontes. 